FIU Law Review

Fall 2012

\title{
The NFL Concussion Litigation: A Critical Assessment of Class Certification
}

Sheila B. Scheuerman

Charleston School of Law

Follow this and additional works at: https://ecollections.law.fiu.edu/lawreview

Part of the Other Law Commons

Online ISSN: 2643-7759

\section{Recommended Citation}

Sheila B. Scheuerman, The NFL Concussion Litigation: A Critical Assessment of Class Certification, 8 FIU L. Rev. 81 (2012).

DOI: https://dx.doi.org/10.25148/lawrev.8.1.10

This Article is brought to you for free and open access by eCollections. It has been accepted for inclusion in FIU Law Review by an authorized editor of eCollections. For more information, please contact lisdavis@fiu.edu. 


\title{
The NFL Concussion Litigation: A Critical Assessment of Class Certification
}

\author{
Sheila B. Scheuerman*
}

\section{INTRODUCTION}

Charles ("Ray") Easterling, starting safety for the Atlanta Falcons in the 1970s, would forget the way home when jogging through his neighborhood. ${ }^{1}$ He would walk into a room and forget why he was there. ${ }^{2}$ He would experience severe mood swings and depression. ${ }^{3}$ In August 2011, Easterling ${ }^{4}$ filed one of the first lawsuits against the $\mathrm{Na}$ tional Football League (NFL), asserting that the NFL concealed the long-term effects of on-field head injury and failed to warn players of the risks of harm from repeated concussions.' As of October 2, 2012, more than 155 similar cases on behalf of thousands of former players have been consolidated in a multi-district litigation case (MDL) in federal district court in Pennsylvania. ${ }^{6}$ The consolidated mega-case seeks, among other things, to certify a national class of "[a]ll retired or former NFL professional football players who reside in the United States, who are not now salaried employees of the NFL or any mem-

\footnotetext{
Director of Faculty Development \& Scholarship, and Professor of Law, Charleston School of Law. I would like to thank Anthony J. Franze and Jeffrey Karlin for their valuable comments on earlier drafts of this Article. In addition, I am grateful to Charleston School of Law librarian William R. Gaskill for his invaluable research assistance. Finally, I would like to thank Stephanie Brown and Megan White for their research and citation assistance. Errors and omissions are mine alone.

1 Mary Ann Easterling, NFL's Head Injury Denial Failed My Husband, USA ToDAY, Aug. 15,2012 , at 7A

2 Joseph A. Slobodzian, Concussion Suits Have NFL, Ex-Players On Collision Course, PHILA. INQUIRER, May 29, 2012, at A1.

3 Mike Tierney, Football Player Who Killed Himself Had Brain Disease, N.Y. TIMES, July 26, 2012, at B16.

4 Easterling later committed suicide on April 19, 2012. E.g., Tierney, supra note 3. The autopsy of Easterling's brain found that he suffered from moderately severe chronic traumatic encephalopathy. Id.; see also infra Part II.

5 Class Action Complaint, Easterling v. Nat'l Football League, No. 2:11-CV-05209-AB (E.D. Pa. Aug. 17, 2011), ECF No. 1 [hereinafter Easterling Complaint].

6 Plaintiffs/Former Players, NFL CONCUSSION LITIGATION, http://nflconcussionlitigation. com/?page_id=274 (last visited Mar. 6, 2013); see also In re Nat'l Football League Players' Concussion Injury Litig., 842 F. Supp. 2d 1378 (J.P.M.L. Jan. 31, 2012).
} 
ber club, and who have not filed a personal injury action for latent brain injury."

In the pantheon of high-stakes class actions, the personal injury class action has long been considered dead. ${ }^{8}$ Too many individual issues, such as causation and medical history, doom the typical personal injury case.' The NFL Players seek to avoid this problem by asserting class claims only for "medical monitoring," a novel theory that allows asymptomatic plaintiffs to recover anticipated costs of medical examinations. ${ }^{10}$

The problem, however, is that a medical monitoring claim presents its own individual issues. Not all states recognize medical monitoring as a cause of action, and even among those that do, the elements vary. ${ }^{11}$ Like a negligence claim, a medical monitoring claim presents individualized causation issues. ${ }^{12}$ In addition, testing and treatment plans can vary from patient to patient. ${ }^{13}$

Part I of this essay describes the "NFL concussion" litigation. Part II provides a brief overview of the science. Part III examines the current standards for class certification, and Part IV applies these standards to the medical monitoring class claims brought by the NFL Players. Part IV notes the courts' uncertainty on whether medical monitoring class actions should be treated as an injunctive class under Federal Rule of Civil Procedure 23(b)(2) or as a damages class under Federal Rule of Civil Procedure 23(b)(3). ${ }^{14}$ Regardless of which category medical monitoring falls into, Part IV concludes that the players' medical monitoring claim as currently pled fails to satisfy the criteria for class certification. This does not mean that these plaintiffs have no redress against the NFL. It means only that the NFL Players need to employ the traditional personal injury lawsuit-not the class action device-to pursue their relief.

7 Plaintiffs' Master Administrative Class Action Complaint for Medical Monitoring II 16, In re Nat'l Football League Players' Concussion Injury Litig., 2:12-MD-02323-AB, MDL No. 2323 (E.D. Pa. June 7, 2012) [hereinafter Master Class Action Complaint], ECF No. 84.

8 See generally RichARD A. NAGAREDA, MASS TORTS IN A WORLD OF SETTLEMENT (2007); see also Castano v. Am. Tobacco Co., 84 F.3d 734, 746 (5th Cir. 1996) (noting that "certification of mass tort litigation classes has been disfavored.").

9 See, e.g., Amchem Prods., Inc. v. Windsor, 521 U.S. 591, 624 (1997) (discussing problems of satisfying Rule 23(b)(3) where plaintiffs alleged exposure to asbestos caused harm).

10 E.g., D. Scott Anderson, Note, A Fifty-State Survey of Medical Monitoring and the Approach the Minnesota Supreme Court Should Take When Confronted with the Issue, 32 WM. MitCHELl L. REV. 1095, 1096-97 (2005).

11 E.g., id. at 1114-17; see also discussion infra Part IV.

12 See sources cited infra notes 222-26.

13 See infra Part III.

14 See infra Part IV. 


\section{THE LAWSUITS}

Suits about concussions are not new. The first concussion ${ }^{15}$ lawsuit involving a professional football player was filed sixteen years ago by Merril Hoge, a former running back for the Pittsburgh Steelers and the Chicago Bears. ${ }^{16}$ In 1996, Hoge filed a medical malpractice action against Dr. John Munsell, the team physician. ${ }^{17}$ Hoge claimed that Dr. Munsell failed to warn him about the risks of returning to the game too quickly after a concussion. ${ }^{18}$ After a two-week trial in June 2000, the jury awarded Hoge $\$ 1.55$ million in damages. ${ }^{19}$

15 "[T]here is no universal agreement on the [medical] definition of a concussion." Robert C. Cantu, Return to Play Guidelines After a Head Injury, 17 ClinICs IN SPORTS MED. 45, 52 (1998). Generally speaking, however, a concussion is a traumatically induced alteration in brain function. See id; see also infra text accompanying notes 90-94; see generally CHRISTOPHER NOWInsKi, HEAD GAMES - FOOTBALl'S CONCUSSION CRISIS FROM THE NFL TO YOUTH LEAGUES 24-25 (2007). Concussions are prevalent in football and boxing, which both involve violent contact, but can occur in all major sports. See Daniel H. Daneshvar et al., The Epidemiology of Sports-Related Concussion, 30 CLINICS IN SPORTS MED. 1, 3-5 (2011) (reporting concussion rates for football, baseball, basketball, cheerleading, ice and field hockey, and soccer). In 2011, for example, eleven Major League Baseball players were placed on the disabled list due to concussions and head injuries. Jon Paul Morosi, MLB Gets Stringent with Concussions, Fox SPORTS (June 15, 2012, 10:03 PM), http://msn.foxsports.com/mlb/story/mlb-gets-tough-withconcussions-7-day-disabled-list-designed-to-protect-players-061412.

16 Alexander N. Hecht, Legal and Ethical Aspects of Sports-Related Concussions: The Merril Hoge Story, 12 SETON HALL. J. SPORT L. 17, 26 (2002). Hoge recently created controversy when he said it was "irresponsible" to suggest that football was a dangerous game for children. Michael David Smith, Merril Hoge: Kurt Warner Is Uneducated and Irresponsible, NBC SPORTS (May 4, 2012, 4:58 PM), http://profootballtalk.nbcsports.com/2012/05/04/merril-hoge-kurtwarner-is-uneducated-and-irresponsible/.

17 Hecht, supra note 16, at 27. Hoge's suit was the first by a professional football player. See id. at 30. Similarly, in March 2010, a former player in the Arena Football League filed a malpractice action against the Colorado Crush's team doctor. E.g., Alan Schwarz, Lawsuit Cites Mishandling of Football Concussion, N.Y. TIMES, Mar. 19, 2010, at B17, available at http://www.nytimes.com/2010/03/19/sports/football/19concussions.html?_r=0.

18 Hecht, supra note 16, at 21. This risk can include "Second Impact Syndrome," where a second blow to the brain causes the athlete to suffer brain stem failure, resulting in respiratory failure and sometimes death. E.g., Robert C. Cantu, Second-Impact Syndrome, 17 CLINICS IN SPORTS MED. 37, 37-44 (1998). Hoge suffered a concussion during a preseason game in August 1994 against the Kansas City Chiefs. Hecht, supra note 16, at 26; see also John Mangels, Players Say NFL Ignored Dangers of Concussions, Cleveland Plain Dealer, May 27, 2012, at A1. "Five days later, without a neurological exam, a doctor cleared him by phone to play." Mangels, supra note 18. At an October 2nd game against the Buffalo Bills, Hoge suffered a second concussion and stopped breathing. Id. After this concussion, Hoge had to keep his home phone number in his wallet in case he forgot how to get home. Peter Kerasotis, Hoge's Story Should Be Warning to NFL, FLORIDA TODAY, Mar. 20, 2011. Less than two weeks later, Hoge retired from the NFL. Hecht, supra note 16, at 27.

19 Hecht, supra note 16, at 28-29. The parties subsequently settled the lawsuit for undisclosed terms. Schwarz, supra note 17. For a thorough discussion of the Hoge case, see Hecht, supra note 16, at 25-30, and Daniel J. Kain, "It's Just A Concussion:" The National Football League's Denial of A Casual Link Between Multiple Concussions And Later-Life Cognitive Decline, 40 RUTGERS L.J. 697, 713-17 (2008). 
What is new in concussion litigation is the defendant. Players are no longer bringing individual medical malpractice suits against team physicians; instead, they are suing the NFL itself. ${ }^{20}$ In July 2011, more than seventy former NFL players and their spouses filed the first lawsuit against the $\mathrm{NFL}^{21}$ in Los Angeles County Superior Court. ${ }^{22}$ Despite the large number of plaintiffs, the suit was not brought as a class action. $^{23}$

This first case, however, opened the doors. Courts across the country were inundated with no less than 155 suits, ${ }^{24}$ including twelve class actions. ${ }^{25}$ While the class actions all essentially sought to represent the same putative class of former players, the class complaints varied in significant respects. ${ }^{26}$ Some class complaints asserted claims

20 E.g., Plaintiffs' Amended Master Administrative Long-Form Complaint, In re Nat'l Football Players' Concussion Injury Litig., No. 2:12-md-02323-AB (E.D. Pa. July 17, 2012), ECF No. 2642. At least one case also has named the individual clubs as defendants. E.g., Complaint, Woods v. NFL, No. 12-10107 (Fla. Cir. Ct. June 26, 2012), available at 2012 WL 3802438 (naming Miami Dolphins, Detroit Lions, Buffalo Bills, Philadelphia Eagles and Tennessee Titans as defendants).

21 Plaintiffs' Complaint for Damages and Demand for Jury Trial, II II 1-85, Maxwell v. Nat'l Football League, No. BC 465842 (Cal. Super. Ct. July 19, 2011) [hereinafter Maxwell Complaint]. The complaint named the National Football League, as well as NFL Properties, LLC, as defendants. In addition, the complaint named various defendants related to Riddell, Inc., a helmet manufacturer. The complaint brought products liability - design defect, manufacturing defect, failure to warn, and negligence - claims against the Riddell defendants. See id. III 567-586.

22 The NFL, with the consent of the Riddell defendants, successfully removed the action to the United States District Court for the Central District of California on the basis of federal question jurisdiction. Memorandum of Law in Support of Motion for Transfer and Coordination Pursuant to 28 U.S.C. $\$ 1407$ at 2, In re Nat'l Football League Litig., MDL No. 2323 (J.P.M.L. Nov. 15, 2011). The defendants argued that Section 301 of the Labor Management Relations Act completely preempted plaintiffs' claims. Id. This argument also forms the basis of the defendants' motion to dismiss. Memorandum of Law of Defendants Nat'l Football League and NFL Properties LLC In Support of Motion to Dismiss the Amended Master Admin. Long-Form Complaint on Preemption Grounds, In re Nat'l Football Players' Concussion Injury Litig., No. 2:12-md-02323-AB (E.D. Pa. Aug. 30, 2012), ECF No. 3589.

23 See generally Maxwell Complaint, supra note 21. Lead plaintiff Vernon Maxwell played professional football for six seasons, and suffered multiple concussions during his pro career. $I d$. III 150-51. The Complaint alleged that Maxwell suffers from various symptoms including memory loss and headaches. Id. If 153. The Maxwell Complaint alleged that the NFL breached its duty to protect its players by failing to warn players of the risks of repeated concussions, id., and by failing to institute rules preventing a player from returning to play after a concussive blow. Id. III 533, 548. The Maxwell Complaint further alleged that "[f]or decades, Defendants have known that multiple blows to the head can lead to long-term brain injury," but that the NFL "made ... material misrepresentations ... that there was no link between concussions and later life cognitive/brain injury." Id. III 113, 124-25, 556. The Maxwell plaintiffs brought causes of action for negligence, "negligent-monopolist," fraud and loss of consortium against the NFL. See generally id.

24 Plaintiffs/Former Players, supra note 6.

25 See discussion infra Part I.A.

26 See discussion infra Part I.A. 
for negligence and fraud, ${ }^{27}$ while others brought only medical monitoring claims. ${ }^{28}$ The class complaints further differed in whether class certification was sought under Federal Rule of Civil Procedure 23(b)(2) or 23(b)(3). ${ }^{29}$ Ultimately, the number of cases grew so large that the cases were consolidated into a federal multidistrict litigation where plaintiffs filed a master class action complaint. ${ }^{30}$

\section{A. The Complaints}

The first class action against the NFL was filed in August 2011 by Charles Easterling in the United States District Court for the Eastern District of Pennsylvania. ${ }^{31}$ The complaint asserted claims for negligence, civil conspiracy, concealment, and medical monitoring. ${ }^{32}$ The Easterling complaint sought certification under Federal Rule of Civil Procedure 23(b)(3) of a nationwide class of all former NFL players who sustained a concussion while playing in the NFL and who have, since retirement, developed physical or mental problems as a result. ${ }^{3{ }^{3}}$ On the medical monitoring claim, the Easterling complaint expanded the class to include current players and future players who suffer a concussion or "concussion like symptoms" and also sought certification under Rules 23(b)(2) and (b)(3).

27 E.g., Plaintiffs' Class Action and Individual Complaint for Damages, And Demand for Jury Trial, Jacobs v. Nat'l Football League, No. 11-CIV-9345 (S.D.N.Y. Dec. 20, 2011).

28 E.g., Class Action Complaint, Wooden v. Nat'l Football League, No. 1:12-CV-20269-JEM (S.D. Fla. Jan. 24, 2012)

29 See discussion infra Part I.A.

30 NFL Asks Federal Judge to Dismiss Concussion Lawsuits, NFL.COM (Aug. 30, 2012 9:52 PM), http:/www.nfl.com/news/story/0ap1000000056716/article/nfl-asks-federal-judge-to-dismissconcussion-lawsuits; see also Master Class Action Complaint, supra note 7.

31 Easterling Complaint, supra note 5.

32 See generally id.

33 Id. II II 31-34. The complaint further divided the class into five sub-classes based on the time period in which the player was employed by a member team. Id.

34 Id. II 59.

35 Id. 
A wave of similar class action complaints followed. ${ }^{36}$ Two were filed in the United States District Court for the Southern District of New York. ${ }^{37}$ These complaints, by putative class representatives Harry Jacobs and Reginald Rucker, brought identical ${ }^{38}$ class action allegations; each sought certification of a nationwide class of former professional football players "who were employed by any member club" of the NFL." The Rucker complaint brought class claims under theories of fraud and medical monitoring, while the Jacobs complaint additionally asserted a negligence class claim. ${ }^{41}$ Both sought certification under Federal Rule of Civil Procedure 23(b)(2). ${ }^{42}$

Three more class action suits were filed in January 2012. ${ }^{43}$ One complaint filed by Andrew Glover, who played for the Raiders, Vikings, and Saints over his ten-year career, ${ }^{44}$ used the identical class action allegations and claims set forth in the Jacobs and Rucker complaints. ${ }^{45}$ Like the Rucker and Jacobs complaints, Glover sought class certification under Rule 23(b)(2). ${ }^{46}$ The other complaint, by Ron Solt,

36 See Plaintiffs' Class Action and Individual Complaint for Damages, and Demand for Jury Trial, Rucker v. Nat'l Football League, No. 11-CIV-9538 (S.D.N.Y. Dec. 27, 2011) [hereinafter Rucker Complaint]; Plaintiffs' Class Action and Individual Complaint for Damages, and Demand for Jury Trial, Jacobs v. Nat'l Football League, No. 11-CIV-9345 (S.D.N.Y. Dec. 20, 2011) [hereinafter Jacobs Complaint]; Class Action and Individual Complaint, Demand for Jury Trial, Glover v. Nat'l Football League, No. 2:12-CV-00287-AB (E.D. Pa. Jan. 19, 2012), ECF No. 1 [hereinafter Glover Complaint]; Plaintiffs' Class Action and Individual Complaint, Solt v. Nat'l Football League, No. 2:12-CV-00262-AB (E.D. Pa. Jan. 18, 2012) [hereinafter Solt Complaint]; Class Action Complaint, Wooden v. Nat'l Football League, No. 1:12-CV-20269-JEM (S.D. Fla. Jan. 24, 2012) [hereinafter Wooden Complaint]; Class Action Complaint and Request for Jury Trial, Hughes v. Nat'l Football League, No. 2:12-CV-00459 (E.D. La. Feb. 17, 2012), ECF No. 1 [hereinafter Hughes Complaint]; Class Action Complaint and Request for Jury Trial, Brooks v. Nat'l Football League, No. 2:12-CV-00941 (E.D. La. Apr. 13, 2012) [hereinafter Brooks Complaint]; Class Action Complaint and Request for Jury Trial, Jackson v. Nat'l Football League, No. 2:12CV-01034 (E.D. La. Apr. 23, 2012) [hereinafter Jackson Complaint]; Class Action Complaint and Request for Jury Trial, Granger v. Nat'l Football League, No. 2:12-CV-01303 (E.D. La. May 18, 2012) [hereinafter Granger Complaint]; Class Action Complaint, LeMaster v. Nat'l Football League, No.120302540 (Phila. Ct. Com. Pl. Mar. 21, 2012) [hereinafter LeMaster Complaint]; Class Action Complaint and Demand for Jury Trial, Haddix v. Nat'l Football League, No. L-136312 (N.J. Super. Ct. Law Div. Mar. 21, 2012) [hereinafter Haddix Complaint].

37 See Jacobs Complaint; supra note 36; Rucker Complaint, supra note 36.

38 Compare Jacobs Complaint, supra note 36, II 15-20, with Rucker Complaint, supra note 36, IIII 84-89.

39 Jacobs Complaint, supra note 36, If 16; Rucker Complaint, supra note 36, II 85.

40 Rucker Complaint, supra note 36, IIII 97-111.

41 Jacobs Complaint, supra note 36, at Count III.

42 Rucker Complaint, supra note 36, II 84; Jacobs Complaint, supra note 36, II 15.

43 E.g., Wooden Complaint, supra note 36 (filed Jan. 24, 2012); Solt Complaint, supra note 36 (filed Jan. 18, 2012); Glover Complaint, supra note 36 (filed Jan. 19, 2012).

44 Glover Complaint, supra note 36, II 13.

45 Compare Glover Complaint, supra note 36, IIII 84-89, with Jacobs Complaint, supra note 36, III 15-20, and Rucker Complaint, supra note 36, II II 84-89.

46 Glover Complaint, supra note 36, II 84. 
a former offensive lineman for the Indianapolis Colts and the Philadelphia Eagles, ${ }^{47}$ started with the same class definition of "all retired or former professional football players in the United States who were employed by any member club" of the NFL, ${ }^{48}$ but identified three subclasses: the Non-Concussion Subclass, the Symptomatic Subclass, ${ }^{50}$ and the Concussion Subclass. ${ }^{51}$ Solt sought certification under all three categories of class action: Rules 23(b)(1), (b)(2), and (b)(3). ${ }^{52}$ The third class action filed in January 2012, Wooden v. NFL, originally defined a limited class focused on second-impact syndrome, ${ }^{53}$ but later revised the class definition to the now-standard, "[a]ll retired or former professional football players in the United States." Wooden asserted only a medical monitoring claim on behalf of the class ${ }^{55}$ and did not identify the specific type of class action asserted. ${ }^{56}$

At least one concussion-related class action was filed against the NFL per month from February to May 2012. ${ }^{57}$ Three federal complaints-Jackson v. NFL, Brooks v. NFL, and Granger v. NFLdefined the class as "[a]ll persons, and spouses of persons, who sustained one or more concussions, or suffered concussion like symptoms, while playing in an NFL football game and who has developed or will develop mental or physical problems as a result of the concussions or

47 Solt Complaint, supra note 36, II 11.

48 Id. II 41.

49 Id. II 42. The Non-Concussion Subclass included "[a]ll other Class members who are asymptomatic and did not sustain any concussion while playing football in the NFL, as determined by the medical monitoring conducted on the Class as a whole." Id.

50 Id. II 43. The Symptomatic Subclass included:

[a]ll Class members who suffered and/or presently suffer from conditions and/or symptoms as a result of one or more concussion(s), or from concussion-like symptoms and/or concussion-related conditions from repetitive traumatic brain injury, such conditions and/or symptoms including concentration problems, memory loss, mood swings, personality changes, headache, fatigue, dizziness, insomnia and excessive drowsiness; episodic disorientation; lack of insight, poor judgment, poor to little impulse control; signs and symptoms of Parkinson's Disease or Alzheimer's Disease (and other conditions that discovery may reveal are related) from their playing football in the NFL.

Id.

51 Id. II 44. The Concussion Subclass included "[a]ll Class members who are asymptomatic but have sustained one or more concussion(s), as determined by the medical monitoring conducted on the Class as a whole, while playing football in the NFL." Id.

52 Id. II 40.

53 Wooden Complaint, supra note 36, II 18.

54 Amended Complaint - Class and Mass Action II 889, Wooden v. Nat'l Football League, 2:12-CV-01037 (E.D. Pa. Apr. 24, 2012), ECF No. 2 [hereinafter Amended Wooden Complaint].

55 Id. III 958-68.

56 Id. II 964 (seeking certification “[p]ursuant to Rule 23").

57 See Hughes Complaint, supra note 36 (filed Feb. 17, 2012); LeMaster Complaint, supra note 36 (filed Mar. 21, 2012); Haddix Complaint, supra note 36 (filed Mar. 21, 2012); Jackson Complaint, supra note 36 (filed Apr. 23, 2012); Granger Complaint, supra note 36 (filed May 18, 2012). 
concussion like symptoms." ${ }^{58}$ This definition thus encompassed both former and current players. ${ }^{59}$ Brooks, Granger, and Jackson asserted only a medical monitoring claim on behalf of the class ${ }^{60}$ and sought certification under both Rules 23(b)(2) and (b)(3). ${ }^{61}$ A fourth federal complaint, Hughes $v$. NFL, used a class definition essentially identical to the Easterling complaint. ${ }^{62}$ Hughes invoked both Rules 23(b)(2) and (b)(3) in support of class certification. ${ }^{63}$ One of the class action complaints was filed in state court but removed to federal court by the NFL. ${ }^{64}$ This complaint, LeMaster v. NFL, essentially used the same class definition as the Solt case, but limited the class to Pennsylvania residents: "[a]ll retired or former professional football players domiciled in the Commonwealth of Pennsylvania who were employed by any member club" of the NFL. ${ }^{66}$ Like the Solt Complaint, the LeMaster Complaint identified three sub-classes: the Non-Concussion Subclass, ${ }^{67}$ the Symptomatic Subclass, ${ }^{68}$ and the Concussion Subclass. ${ }^{69}$

58 Jackson Complaint, supra note 36, II 122; Granger Complaint, supra note 36, II 130; Brooks Complaint, supra note 36, II 106.

59 Jackson Complaint, supra note 36, II 185; Granger Complaint, supra note 36, II 209.

60 Jackson Complaint, supra note 36, IIII 179-85; Granger Complaint, supra note 36, IIII 198209; Brooks Complaint, supra note 36, II II 163-69.

61 Jackson Complaint, supra note 36, II 122; Granger Complaint, supra note 36, II 130; Brooks Complaint, supra note 36, II 106.

62 Compare Hughes Complaint, supra note 36, II 115, with Easterling Complaint, supra note 5, II 34. The Hughes Complaint defined the class as "[a]11 persons, and spouses of persons, who sustained one or more concussions, or suffered concussion like symptoms, while playing in an NFL football game and who has developed or will develop mental or physical problems as a result of the concussions or concussion like symptoms.” Hughes Complaint, supra note 36, II 115.

63 Hughes Complaint, supra note 36, II 115.

64 See Docket, LeMaster v. Nat'l Football League, No. 120302540 (Phila. Ct. Comm. Pl. Mar. 21, 2012) (noting Notice of Removal by National Football League filed on May 7, 2012). A second class action complaint was filed during this time period in New Jersey state court. See Haddix Complaint, supra note 36. The Haddix case was removed to federal court and transferred to the United States District Court for the Eastern District of Pennsylvania pursuant to the MDL Order. See Conditional Transfer Order (CTO-12), In re Nat'l Football League Players' Concussion Injury Litig., MDL No. 2323 (J.P.M.L. June 14, 2012); see also infra Part I.B. In the MDL, the Haddix plaintiffs subsequently dropped the class allegations from their short form complaints. Short Form Complaints, In re Nat'l Football League Players' Concussion Injury Litig., No. 2:12-CV-03532-AB (E.D. Pa. Aug. 31, 2012), ECF Nos. 2-4 (filed by Gregory Brown, Lawrence Watkins and Michael Haddix, lead plaintiffs in the state class action).

65 Compare LeMaster Complaint, supra note 36, II II 22-25, with Solt Complaint, supra note 36, III 41-44.

66 LeMaster Complaint, supra note 36, II 22.

67 Id. II 23. The Non-Concussion Subclass included "[a]ll other Class members who are asymptomatic and did not sustain any concussion while playing football in the NFL, as determined by the medical monitoring conducted on the Class as a whole." Id.

68 Id. II 25. The Symptomatic Subclass included:

[a]11 Class members who suffered and/or presently suffer from conditions and/or symptoms as a result of one or more concussion(s), or from concussion-like symptoms and/or concussion-related conditions from repetitive traumatic brain injury, such conditions and/or symp- 
LeMaster invoked the state-law equivalents of Rules 23(b)(2) and (b) (3).

\section{B. The MDL \& Master Administrative Complaint}

Facing these multiple class actions as well as thousands of individual claims, the NFL filed a motion to consolidate the concussion cases with the United States Judicial Panel on Multidistrict Litigation pursuant to 28 U.S.C. $\S 1407$. $^{71}$ With little analysis, the Panel granted the NFL's motion. ${ }^{72}$ With Solt, Glover, and Easterling already pending before Judge Anita Brody of the United States District Court for the Eastern District of Pennsylvania, ${ }^{73}$ the Panel centralized the MDL before Judge Brody. ${ }^{74}$ The MDL now involves over 4,000 players in over 200 complaints.

Pursuant to a case management order, ${ }^{76}$ plaintiffs filed two master administrative complaints, one for individual claims ${ }^{77}$ and the other a class action for medical monitoring. ${ }^{78}$ The new master class action complaint ("Master Class Complaint") included all eleven of the separate class actions, as well as a new class action led by putative class representative Gerald Allen, a former running back for the Baltimore Colts and Washington Redskins. ${ }^{80}$ The apparent purpose of the

toms including concentration problems, memory loss, mood swings, personality changes, headache, fatigue, dizziness, insomnia and excessive drowsiness; episodic disorientation; lack of insight, poor judgment, poor to little impulse control; signs and symptoms of Parkinson's Disease or Alzheimer's Disease (and other conditions that discovery may reveal are related) from their playing football in the NFL.

Id.

69 LeMaster Complaint, supra note 36, II 24. The Concussion Subclass included "[a]11 Class members who are asymptomatic but have sustained one or more concussion(s), as determined by the medical monitoring conducted on the Class as a whole, while playing football in the NFL." Id.

70 LeMaster Complaint, supra note 36, III 21-25 (citing Pennsylvania Rule of Civil Procedure $1708(a) \&(b))$.

71 Section 1407 allows consolidation for pretrial proceedings where pending civil actions in different districts involve "one or more common questions of fact." 28 U.S.C. § 1407(a) (1976).

72 Order, In re Nat'l Football League Players' Concussion Injury Litig., 2:12-MD-02323AB, MDL No. 2323 (J.P.M.L. Jan. 31, 2012), ECF No. 1.

73 See sources cited supra note 36.

74 See In re Nat'l Football League Players' Concussion Injury Litig., 842 F. Supp. 2d 1378 (J.P.M.L. Jan. 31, 2012)

75 See generally Plaintiffs/Former Players, supra note 6.

76 Case Management Order No. 2, In re Nat'l Football League Players' Concussion Injury Litig., 2:12-MD-02323-AB, MDL No. 2323 (E.D. Pa. April 26, 2012), ECF No. 64.

77 Plaintiffs' Master Administrative Long-Form Complaint, In re Nat'l Football League Players' Concussion Injury Litig., 2:12-MD-02323-AB, MDL No. 2323 (E.D. Pa. June 7, 2012), ECF No. 83.

78 Master Class Action Complaint, supra note 7.

79 See discussion supra Part I.A.

80 Master Class Action Complaint, supra note 7, II 5. 
Master Class Complaint is to identify appropriate class representatives for both a national class as well as two state-wide classes.

Unlike the original class complaints, ${ }^{82}$ the Master Class Complaint asserts a class under Federal Rule of Civil Procedure 23(b)(2) only. The complaint alleges six common questions of law or fact that warrant class certification: liability on a claim for medical monitoring; defendant's affirmative defenses; causation; “[w] hether medical monitoring is reasonably necessary for members of the Class to obtain early diagnosis of latent brain injury;" "[w]hether such monitoring is beyond the routine medical care provided to men of a similar age as members of the Classes;" and "[w]hether early diagnosis of latent brain injury will lead to improved treatment for the medical, cognitive, psychological and behavioral sequelae of the latent brain injury." The class identifies a "national class," defined as "[a]ll retired or former NFL professional football players who reside in the United States, who are not now salaried employees of the NFL or any member club, and who have not filed a personal injury action for latent brain injury." Alternatively, the Master Class Complaint defines two state class actions for California and Florida residents.

The Master Class Complaint asserts an independent medical monitoring claim under New York law on behalf of the national class. The class seeks an "injunction creating a Court-supervised NFLfunded comprehensive medical monitoring program for the Plaintiffs and the members of the Class," in the form of a trust fund. ${ }^{88}$ Additionally, the complaint brings a fraudulent concealment/negligent omission claim and seeks medical monitoring as a remedy.

\section{THE SCIENCE}

In simplest terms, a concussion occurs when external force causes the brain to hit the skull inducing an alteration in brain function."

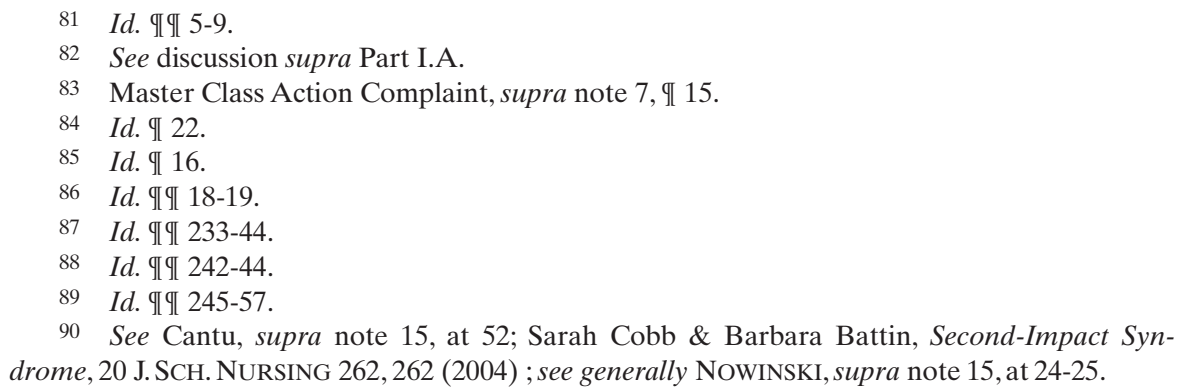


Loss of consciousness is not required for a concussion to occur. ${ }^{91} \mathrm{Neu}-$ rological exams, such as magnetic resonance imaging or electroencephalograms, typically do not detect a concussion. ${ }^{92}$ Rather, diagnosticians must rely on clinical symptoms such as dizziness or nausea." Many use the "Cantu grading system", developed by Dr. Robert C. Cantu, co-founder of the Sports Legacy Institute, which categorizes concussions based on whether the player loses consciousness and suffers amnesia. ${ }^{94}$

When the brain experiences frequent trauma, Chronic Traumatic Encephalopathy (CTE) may occur in the brain. ${ }^{95}$ CTE is a neurodegenerative disease caused by the accumulation of naturally occurring tau proteins in individual nerve cells thereby preventing the cells from connecting with other nerve cells and eventually "killing the cells." In simpler terms, the tau proteins operate "sort of like sludge, which clogs up the brain cell." ${ }^{97}$ Dr. Ann McKee, a leading researcher on CTE, has developed a four-tier grading system for CTE:

In Grade 1, a few hot spots appear on the surface, clustered around small blood vessels .... In Grade 2, the spots multiply but most brain tissue is undisturbed .... In Grade 3, the neurofibulary tangles she likens to skeins of unraveling yarn invade multiple lobes of the brain. Besieged, the medial temporal lobe atrophies. The hippocampus, essential for memory and learning, is attacked. The amygdale, which governs aggressiveness and rage, is assaulted ... . Grade 4, a more florid form of Grade 3, is generally only seen in those who live with the disease longer."

Clinically, CTE presents cognitive, mood, and behavioral symptoms. Initially called "punch drunk syndrome" because of its associa-

91 Mark Aubry, et al., Summary and Agreement Statement of the First International Conference on Concussion in Sport, Vienna 2001, 36 BRIT. J. SPORTS MED. 6, 6 (2002), available at http://bjsm.bmj.com/content/36/1/6.full; accord Cobb \& Battin, supra note 90, at 263.

92 Cobb \& Battin, supra note 90 , at 262. Indeed, after a concussion, "brain scans are [usually] normal because the injury is metabolic rather than structural." Id.

93 Id. at 262-63.

94 Cantu, supra note 15, at 53-56.

95 Robert C. Cantu, Chronic Traumatic Encephalopathy in the National Football League, 61 NEUROSURGERY 223, 223-24 (2007).

96 Legal Issues Relating to Football Helmet Injuries (Part I \& II): Hearings Before the H. Comm. on the Judiciary, 111th Cong. 1, 153 (2010) (statement of Dr. Ann C. McKee) [hereinafter Helmet Injuries Hearings]; see also id. at 67 (statement of Dr. Robert Cantu).

97 Id. at 212 (statement of Dr. Julian Bailes).

98 Jane Leavy, The Woman Who Would Save Football, GRANTLAnd (Aug. 17, 2012), http://www.grantland.com/story/_/id/8218700/neuropathologist-dr-ann-mckee-accused-killingfootball-be-sport-only-hope.

99 Cantu, supra note 95, at 223-24; accord Christine M. Baugh et al., Chronic Traumatic Encephalopathy: Neurodegeneration Following Repetitive Concussive and Subconcussive Brain 
tion with boxers, CTE was first described in 1928 by Dr. Harrison S. Martland, a New Jersey pathologist. ${ }^{100}$ Dr. Martland described the "punch drunk" boxer as exhibiting "slight mental confusion," "unsteadiness in gait," "hesitancy in speech," and "tremors of the hands."101 He further noted that, in later stages, symptoms "often mimic those seen in diseases characterized by the parkinsonian syndrome." though he could not prove his theory, Dr. Martland attributed these degenerative effects to "degenerative progressive lesions" in the brain caused by single or repeated blows to the head.

Studies in the 1950s and 1960s confirmed Martland's earlier findings. ${ }^{104}$ By 1952, moreover, the medical community was recognizing that sub-concussive impacts also had the potential to cause brain damage. $^{105}$ That same year, Dr. Augustus Thorndike, a Harvard surgeon, issued a medical study addressing college sports injuries, and recommended that football players who had been knocked unconscious even once should stop playing the game. ${ }^{106}$ As of 2009 , medical literature described 49 cases of CTE since 1928, "39 of whom were boxers." 107

In part, the rather limited number of diagnosed cases over that seventy-year period may have reflected the difficulty of diagnosing CTE. "Differential diagnosis of most cases of moderate-severe dementia is difficult just based on current presentation." ${ }^{108}$ Rather, CTE can be diagnosed only post-mortem. ${ }^{109}$ Although symptoms are similar to other neurodegenerative diseases, CTE is pathologically distinct from other diseases including Alzheimer's disease and Frontotemporal Lobar Degeneration. ${ }^{110}$ In 1973, Dr. J. A. N. Corsellis identified the

Trauma, EPUB at 3 (May 3, 2012), available at http://www.bu.edu/cste/files/2012/05/ Baugh_Chronic-Traumatic-Encephalopathy_2012.pdf.

100 Harrison S. Martland, Punch Drunk, 91 J. AM. MED. Ass'N 1103, 1103 (1928); see also A. H. Roberts, BRAIN DAMAGE In BoXeRs 13 (1969) (describing Martland's work in this area).

101 Martland, supra note 100, at 1103.

102 Id.

103 Id.

104 See Ewald W. Busse \& Albert J. Silverman, Electroencephalographic Changes in Professional Boxers, 149 J. AM. MED. Ass'N 1522, 1522 (1952). See generally RoBERTs, supra note 100 (discussing results of study of traumatic encephalopathy in British boxers).

105 See Busse \& Silverman, supra note 104, at 1522 (noting that "[i]f the trauma is ... mild but repeated at intervals that do not permit the brain to return to normal functioning, permanent damage may result").

106 Augustus Thorndike, Serious Recurrent Injuries of Athletes - Contraindications to Further Competitive Participation, 247 NEW. ENG. J. MED. 554, 555-56 (1952).

107 Chronic Traumatic Encephalopathy, SPORTS LEGACY INSTITUTE, http://sportslegacy.org/ research/what-is-cte/ (last visited Oct. 13, 2012).

108 Baugh, supra note 99, at 3.

109 Id. at 6, 9.

110 Id. at 2. 
neuropathology of CTE in four different portions of the brain by examining the brain tissue of fifteen deceased boxers. ${ }^{111}$ Specifically, Corsellis noted neurofibrillary tangles spread diffusely through both the cerebral cortex and the brainstem.

In 2005, Dr. Bennet Omalu, a forensic pathologist at the University of Pittsburgh, ${ }^{113}$ identified the first documented case of CTE in a former professional football player. ${ }^{114}$ In this study, Dr. Omalu examined the brain tissue of Hall of Fame offensive lineman "Iron Mike" Webster $^{115}$ and found tau protein buildup characteristic of CTE. ${ }^{116}$ In 2006, Dr. Omalu confirmed a second case of CTE in a professional football player, Terry Long, a former player for the Pittsburgh Steelers, who committed suicide by drinking anti-freeze. ${ }^{117}$ And in 2007, Omalu diagnosed CTE in a third former football player, Andre Waters, a former defensive back for the Philadelphia Eagles and Arizona Cardinals. ${ }^{118}$ In a telephone interview, Dr. Omalu told the New York Times that "brain trauma 'is the significant contributory factor' to Mr. Waters's brain damage.",

111 J.A.N. Corsellis et al., The Aftermath of Boxing, 3 PsYCHOL. MED. 270 (1973).

112 Id. at 296

113 E.g., Alan Schwarz, Expert Ties Ex-Player's Suicide to Brain Damage, N.Y.TIMES, Jan. 18, 2007, at A1.

114 Bennet I. Omalu et al., Chronic Traumatic Encephalopathy in a National Football League Player, 57 NEUROSURGERY 128 (2005).

115 Webster played center for the Pittsburgh Steelers for fourteen years, and earned the nickname "Iron Mike" by "playing six straight seasons without missing an offensive down." Art Carey, Big Men of the NFL Pay for Their Play Later in Life, PHILA. INQUIRER, Jan. 27, 2003; see also Webster's Estate Triumphs, SEATTLE TIMES (Dec. 15, 2006), http://seattletimes.com/html/sports/2003478503_nfl15.html (same); Hard Knocks That Can Last a Lifetime, POST-CRESCENT, Nov. 28, 2010 (describing Webster's career as a "star offensive lineman").

116 Omalu, supra note 114, at 128; see also Cantu, supra note 95, at 223. Webster's estate subsequently sued the National Football League for disability benefits under the League's retirement plan. See Jani v. Bert Bell/Pete Rozelle NFL Player Retirement Plan, 209 Fed. Appx. 305 (4th Cir. 2006). A federal judge awarded Webster's family over $\$ 1$ million. See Don Markus, Ex-Redskin Player Sues for Added Disability Payments, BALT. SUN (Nov. 29, 2010), http://articles.baltimoresun.com/2010-11-29/news/bs-md-shelton-nfl-suit-20101129_1_disabilitydoug-ell-cy-smith (reporting Webster's family received $\$ 1.2$ million in disability payments); Michael Leahy, The Pain Game, WASH. POST (Jan. 30, 2008), http://articles.washingtonpost.com/2008-02-03/news/36840014_1_pain-pills-pain-game-surgeries (reporting award of \$1.5 million); see also Brett Edwin LoVellette, Comment, "Mortal [K]ombat in Cleats": An Examination of the Effectiveness of the National Football League's Disability Plan and Its Impact on Retired Players, 36 PEPP. L. REV. 1101, 1127-33 (2009) (describing Webster's quest for disability benefits).

117 Bennet I. Omalu et al., Chronic Traumatic Encephalopathy in a National Football League Player: Part II, 59 NeUROSURGERY 1086 (2006); see also Cantu, supra note 95, at 223.

118 See Cantu, supra note 95, at 223.

119 Schwarz, supra note 113. 
A 2005 study by the Center for the Study of Retired Athletes at the University of North Carolina corroborated Dr. Omalu's findings. ${ }^{120}$ Dr. Kevin M. Guskiewicz surveyed more than 2,500 former players and found that retired NFL players who had a history of three or more concussions were five times more likely to develop "mild cognitive impairment," and three times more likely to experience "significant memory problems" when compared to retirees without a history of concussions. ${ }^{121}$ Another survey by Dr. Guskiewicz in 2007 found that "football players with three or more concussions are at a threefold risk for sustaining future concussions, and subsequently three times more likely to be diagnosed with clinical depression."

In 2008, Boston University Medical School partnered with the Sports Legacy Institute to create the Center for the Study of Chronic Traumatic Encephalopathy ("Center"), which is dedicated to conducting research on CTE. ${ }^{123}$ Between February 2008 and June 2010, the Center analyzed the brains of twelve professional football players. ${ }^{124}$ All twelve showed evidence of CTE. ${ }^{125}$ To date, $93 \%$ of the professional football players' brains tested by the Center have been diagnosed with CTE.

Still, not all former professional football players have exhibited symptoms of CTE; ${ }^{127}$ Associate Justice Byron "Whizzer" White is a notable example. ${ }^{128}$ Predicting CTE is difficult. Presently, CTE cannot

120 See Kevin M. Guskiewicz et al., Association Between Recurrent Concussion and LateLife Cognitive Impairment in Retired Professional Football Players, 57 Neurosurgery 719 (2005).

121 Id.

122 Kevin M. Guskiewicz et al., Recurrent Concussion and Risk of Depression in Retired Professional Football Players, MED. \& SCI. In SPORTS \& EXERCISE 903, 906 (2007). For an overview of the competing studies sponsored by the NFL, see Michelle Modery, Injury Time-Out: Justifying Workers' Compensation Awards to Retired Athletes With Concussion-Caused Dementia, 84 TEMPLE L. REV. 247, 265-67 (2011).

123 See BU Center for the Study of Chronic Traumatic Encephalopathy, http://www.bu.edu/cste/ (last visited Oct. 13, 2012).

124 Brandon E. Gavett et al., Chronic Traumatic Encephalopathy: A Potential Late Effect of Sport-Related Concussive and Subconcussive Head Trauma, 30 CLINICS IN SPORTS MED. 179, 180 (2011).

125 Id. Dr. Gavett acknowledged that the results include a selection bias as the brains are donated to the Center for study, and no randomized study has been conducted. Id. Using the total number of professional football player deaths for that time period, Dr. Gavett estimated a lifetime prevalence of CTE of $3.7 \%$. Id.

126 Alan Schwarz, The Next Step for Researchers Is Not Finding Brain Trauma, N.Y. TIMES, May 8, 2011, at SP, available at http://www.nytimes.com/2011/05/08/sports/football/ 08duerson.html?_r=0.

127 See, e.g., Helmet Injuries Hearings, supra note 96, at 67 (statement of Dr. Robert C. Cantu) (noting that "not every athlete who experiences head trauma develops [CTE]").

128 See Dennis J. Hutchinson, The Man Who Once Was Whizzer White (1998). White played professional football for three seasons, playing for one year with the Pittsburgh Pirates (now Steelers), id. at 97-122, and two with the Detroit Lions. Id. at 158-170. At \$15,000, 
be diagnosed during a person's lifetime. ${ }^{129}$ Unlike other diseases such as Alzheimer's, “[t]here are neither published and validated clinical diagnostic criteria nor biomarkers" for CTE.

Indeed, researchers do not yet understand the underlying mechanisms that cause the disease. ${ }^{131}$ Repeated brain trauma is just one risk factor for CTE. A 2012 Study by the Center noted that "there are numerous individuals with a history of repeated brain trauma who do not have CTE upon neuropathological examination. Therefore, concussions and other brain trauma alone are not sufficient to cause the disease." "[O]ther factors, including duration of exposure to head trauma, age at first exposure, gender, age, race, and genetic predisposition, may play a role in the development of CTE." ${ }^{133}$ For example, in congressional testimony, Dr. Robert Cantu noted that the Center had identified "a case of CTE in a man who only played football at the college level," and concluded that "some of these individuals have entered the NFL already with incipient, if not full-blown, CTE." ${ }^{, 134}$ Additionally, a player's position could play a role. ${ }^{135}$ A recent study by Dr. Everett Lehman at the National Institute for Occupational Safety and Health found that players in "speed positions," such as quarterbacks, running backs, wide receivers, and linebackers, had more than three times the risk of dying from a neurodegenerative disease, such as Alzheimer's, than non-speed position players, such as defensive lineman. ${ }^{136}$

Moreover, although the research suggests that brain trauma is a risk factor for CTE, "very little is known about what type, frequency, or amount of trauma is necessary to induce the accumulation of these

White was the highest-paid player of his day. THE Supreme COURT JustiCES ILlustrated BIOGRAPHIES, 1789-1995, 462 (Clare Cushman ed. 1995). Another notable example is Associate Justice Alan C. Page of the Minnesota Supreme Court. See Herbert M. Kritzer, Law is the Mere Continuation of Politics by Different Means: American Judicial Selection in the Twenty-First Century, 56 DePaul L. REV. 423, 437-38 (2007). Before winning a seat on the Minnesota Supreme Court in 1992, Page was a Hall of Fame defensive lineman for the Minnesota Vikings in the 1960 s and 1970 s. Id.

129 Baugh, supra note 99, at 3,6,9.

130 Id. at 9.

131 Id. at 5-6.

132 Id. at 5.

133 Id. at 9.

134 Helmet Injuries Hearings, supra note 96, at 67 (statement of Dr. Robert C. Cantu).

135 Baugh, supra note 99, at 5; see also Everett J. Lehman et al., Neurodegenerative Causes of Death Among Retired National Football League Players, 79 NEURology (Sept. 10, 2012), available at http://www.neurology.org/content/early/2012/09/05/WNL.0b013e31826daf50. This difference reflects the different concussion rates experienced by the different positions: "[C]oncussions most often occur while the player is making a tackle (43\%), being tackled (23\%), blocking (20\%), or being blocked (10\%)." Cantu, supra note 15, at 53.

136 Lehman, supra note 135 , at 3-4. 
pathological proteins." ${ }^{137}$ Recent findings indicate that subconcussive impact that does not result in any clinical symptoms may itself be sufficient to initiate CTE. ${ }^{138}$

Finally, not all football players with a history of concussions exhibit clinical signs of CTE. It may be that some players are resilient to the disease for various reasons and may remain asymptomatic even though their brains will show the tau proteins and other pathologies that indicate CTE at death. ${ }^{139}$ As Dr. Ann C. McKee, ${ }^{140}$ co-director of the Center explained, "[s]ome individuals who are intelligent and have great capacity for rewiring their nervous system or taking different routes to access the same information can have a lot of structural damage without exhibiting any symptoms.. ${ }^{141}$

\section{General PRINCIPLES OF ClASS CERTIFICATION}

To certify a class action, a plaintiff must satisfy the prerequisites of Rule 23(a): (1) numerosity, (2) commonality, (3) typicality, and (4) adequate representation. ${ }^{142}$ Then, the class action must fit within one of the categories of Rule 23(b), specifically either an injunctive class under Rule 23(b)(2) or a damages class under Rule 23(b)(3). ${ }^{14}$

Wal-Mart v. Dukes ${ }^{144}$ is the Supreme Court's most recent class action decision. Wal-Mart involved "one of the most expansive class actions ever." ${ }^{145}$ In Wal-Mart, the district court certified a Rule 23(b)(2) injunctive class of nearly 1.5 million current and former fe-

137 Brandon E. Gavett et al., Mild Traumatic Brain Injury: A Risk Factor for Neurodegeneration, 2:18 ALZHEIMER's RES. \& THERAPY 1, 2 (2010), available at http://alzres.com/content/pdf/alzrt42.pdf.

138 Baugh, supra note 99, at 5.

139 See, e.g., Schwarz, supra note 126.

140 Dr. McKee has been described as "[t]he woman who would save football." Jane Leavy, The Woman Who Would Save Football, GrantLAND (Aug. 17, 2012), http://www.grantland.com/story/_id/8218700/neuropathologist-dr-ann-mckee-accused-killingfootball-be-sport-only-hope.

141 See, e.g., Schwarz, supra note 126.

142 FED. R. CIV. P. 23(a). For a thorough discussion of the requirements to certify a class, see 1 Alba Conte \& Herbert B. Newberg, Newberg on Class ACtions ch. 3 (4th ed. 2002).

143 Two categories are not relevant here. First, Rule 23(b)(1)(A) allows a class action where the suit presents a risk of "inconsistent or varying adjudications with respect to individual class members that would establish incompatible standards of conduct for the party opposing the class." "This category is somewhat opaque and rarely utilized." 1 ALBA CONTE \& HERBERT B. Newberg, Newberg on Class Actions § 1:7 (4th ed. 2002). Second, Rule 23(b)(1)(B) also permits a class action where "the judgment in a nonclass action, while not technically concluding the rights of other members, might do so as a practical matter." Id. The classic example of a Rule 23(b)(1)(B) class action is the limited fund class action. See id.; see also Amchem Prods., Inc. v. Windsor, 521 U.S. 591, 614 (1997) (describing “'limited fund' cases . . . in which numerous persons make claims against a fund insufficient to satisfy all claims").

144131 S. Ct. 2541 (2011).

145 Id. at 2547 
male employees of Wal-Mart who alleged that the company discriminated against them on the basis of sex in violation of Title VII. ${ }^{146}$ The class sought injunctive and equitable relief, including backpay. ${ }^{147}$ In Wal-Mart, the Court clarified two things about class certification. First, the Court clarified the meaning of "commonality" under Rule 23(a). ${ }^{148}$ Second, the Court added to our understanding of when a Rule 23(b)(2) class is appropriate. ${ }^{149}$

\section{A. Commonality After Wal-Mart v. Dukes}

As a threshold requirement, Rule 23(a)(2) requires all class action plaintiffs to show that "there are questions of law or fact common to the class." In Wal-Mart, the Court noted that this "language is easy to misread, since "[a]ny competently crafted class complaint literally raises common "questions." "151 Rather, the Court explained that "[c]ommonality requires the plaintiff to demonstrate that the class members "have suffered the same injury." "152 The Court elaborated that commonality requires a "common contention ... that is capable of classwide resolution-which means that determination of its truth or falsity will resolve an issue that is central to the validity of each one of the claims in one stroke." 153 In short, commonality requires "common answers," not merely common questions.

Applying this standard, the Court found that the case did not present "even a single common question." "The Court noted that the plaintiffs' sex discrimination claim was based on an alleged "pattern or practice of discrimination" for "literally millions of employment decisions." The Court concluded that "[w]ithout some glue holding the alleged reasons for all those decisions together, it will be impossible to say that the examination of all the class members' claims for relief will produce a common answer to the crucial question why was I disfavored." ${ }^{, 157}$ In doing so, the Court emphasized that individual store managers may have had various sex-neutral criteria for hiring and

146 Id.

147 Id. at 2547.

148 Wal-Mart,131 S. Ct. at 2550-57.

149 Id. at 2557-61.

150 FED. R. CIV. P. 23(a)(2).

151 Wal-Mart, 131 S. Ct. at 2551 (quoting Richard Nagareda, Class Certification in the Age of Aggregate Proof, 84 N.Y.U. L. REV. 97, 131-32 (2009)).

152 Id. at 2551 (quoting Gen. Tel. Co. of Sw. v. Falcon, 457 U.S. 147, 157 (1982)).

153 Id.

154 Id.

155 Id. at 2556.

156 Id. at 2552.

157 Wal-Mart, 131 S. Ct. at 2552. 
promotion. ${ }^{158}$ Responding to the dissent's criticism that the Court was "blending" the commonality requirement with the predominance requirement of Rule 23(b)(3), the Court explained that dissimilarities were relevant to determining whether a common question existed. ${ }^{159}$

B. Rule 23(b)(2)

Rule 23(b)(2) permits a class action where "the party opposing the class has acted or refused to act on grounds that apply generally to the class, so that final injunctive relief or corresponding declaratory relief is appropriate respecting the class as a whole." ${ }^{160}$ In Wal-Mart, the Court held that claims for individualized relief are not permitted under Rule 23(b)(2). ${ }^{16}$

As a threshold matter, the Court noted the defendant's right to raise any individual affirmative defenses. ${ }^{162}$ The Court explained that "[b]ecause the Rules Enabling Act forbids interpreting Rule 23 to 'abridge, enlarge or modify any substantive right,' a class cannot be certified on the premise that Wal-Mart will not be entitled to litigate its statutory defenses to individual claims." ${ }^{163}$ Under this reasoning, a Rule 23(b)(2) class should not be certified where the defendant has plaintiff-specific affirmative defenses.

Additionally, the Court subtly changed the mode of analysis for a Rule 23(b)(2) class. Instead of analyzing whether the claim was "equitable" or legal in nature, ${ }^{164}$ the Court instead focused on the "indivisible nature" of the remedy. ${ }^{165}$ The Court explained:

Rule 23(b)(2) applies only when a single injunction or declaratory judgment would provide relief to each member of the class. It does not authorize class certification when each individual class member would be entitled to a different injunction or declaratory judgment against the defendant. Similarly, it does not authorize class certification when each class member would be entitled to an individualized award of monetary damages. ${ }^{166}$

158 Id. at $2555-56$.

159 Id. at 2556.

160 FED. R. CIV. P. 23(b)(2).

161 Wal-Mart, 131 S. Ct. at 2557. The Court left for another day whether Rule 23(b)(2) prohibits any claim for monetary relief at all. $I d$.

162 Id. at 2561.

$163 I d$. (citations omitted).

164 E.g., Arch v. Am. Tobacco Co., 175 F.R.D. 469, 481-82 (1997).

165 Wal-Mart, 131 S. Ct. at 2557; see also id. at 2560 (noting that it was "irrelevant" that plaintiffs' claim for back-pay was "equitable in nature").

$166 I d$. at 2557. 
The Court noted that Rule 23(b)(2) lacked the procedural protections of Rule 23(b)(3), including the opportunity to opt-out of the class action $^{168}$ and the mandatory notice provisions of Rule 23(b)(3). ${ }^{169}$ The Court explained that these protections were "unnecessary to a (b)(2) class" because the relief of an "indivisible injunction" benefits all class members at once. ${ }^{170}$ The assumption here is that the relief benefits all class members equally, so that there should be no need for any individualized or case-specific inquiries. Likewise, notice and optouts have "no purpose" where the indivisibility of the requested relief assures that all class members benefit. ${ }^{171} \quad$ As an example, the Court identified the challenges to racial segregation-"conduct that was remedied by a single classwide order"—as the quintessential (b)(2) cases. $^{172}$

This focus on the indivisible nature of the remedy can also be seen in the American Law Institute's Principles of the Law of Aggregate Litigation. Under the ALI's approach, "indivisible remedies," which are appropriate under Rule 23(b)(2), "generally stand to benefit or otherwise affect all persons subject to the disputed policy or practice." ${ }^{173}$ Rejecting an analysis that tried to categorize the requested relief "along the law-equity divide," 174 the Principles instead urged courts to look at the "practical operation of the remedy." cifically addressing medical monitoring class actions, the Principles noted that "[e]ven when medical-monitoring claims are allowed, there is no basis of aggregating claims that ultimately rely on individual considerations to prove liability." ${ }^{176}$

Finally, reflecting the Court's concerns about the lack of opt-out opportunity in a (b)(2) class, many circuits require that a (b)(2) class action demonstrate that the class's claims are "cohesive."

167 Id. at 2558.

168 Compare FED. R. CIV. P. 23(c)(2)(B)(v) (allowing class members to opt-out of a (b)(3) class action), with FED. R. CIV. P. 23(c)(2)(A) (failing to provide opt-out right to (b)(3) class members).

169 Compare FED. R. CIV. P. 23(c)(2)(B) (requiring damages class members to receive the "best notice that is practicable under the circumstances"), with FED. R. CIV. P. 23(c)(2)(A) (stating that for injunctive classes, notice is discretionary).

170 Wal-Mart, 131 S. Ct. at 2558.

171 See id. at 2559.

172 Id. at 2557-58.

173 A.L.I., PRinciples of THE LAW OF AGgRegAte Litig. § 2.04, at 117 (2010).

174 Id. at 119.

175 Id.

176 Id. at 121.

177 M.D. ex rel. Stukenberg v. Perry, 675 F.3d 832, 847 (5th Cir. 2012); Gates v. Rohm \& Hass Co., 655 F.3d 255, 269 (3d Cir. 2011); Blackman v. Dist. of Columbia, 633 F.3d 1088, 1094 (D.C. Cir. 2011); Avritt v. Reliastar Life Ins. Co., 615 F.3d 1023, 1035 (8th Cir. 2010); Romberio v. Unumprovident Corp., 385 Fed. Appx. 423, 433 (6th Cir. 2009); Shook v. Bd. of Cnty. Comm'rs, 
siveness requirement looks at whether individual issues prevent adjudication of the class's claims on an aggregate basis. ${ }^{178}$ In Barnes $v$. American Tobacco Co., for example, the United States Court of Appeals for the Third Circuit explained that cohesiveness requires that the plaintiffs' injuries must be "group, as opposed to individual injuries." action, the cohesiveness requirement focuses on a lack of individualized issues. $^{180}$

\section{Rule 23(b)(3)}

To certify a damages class under Rule 23(b)(3), a proposed class action must satisfy the elements of predominance and superiority. First, a court must find that "the question of law or fact common to the class members predominate over any questions affecting only individual members." "181 Second, the court must conclude "that a class action is superior to other available methods for fairly and efficiently adjudicating the controversy." "In short, this analysis weighs individual issues against common issues: do the claims of the proposed class involve facts or legal issues unique to each class member, or can the issues be resolved on a class-wide basis?"

Both factual and legal differences can raise individual issues. In terms of factual differences, the facts of exposure and each plaintiff's medical history may vary widely. ${ }^{184}$ In turn, "factual differences translate into significant legal differences." exposure or injury can require disparate application of legal rules, such as causation and comparative fault. ${ }^{186}$ Finally, in a national class action, "variations in state law may swamp any common issues and defeat predominance."

543 F.3d 597, 604 (10th Cir. 2008); Lemon v. Int'l Union of Operating Eng'rs, Local No. 139, AFLCIO, 216 F.3d 577, 580 (7th Cir. 2000); Barnes v. Am. Tobacco Co., 161 F.3d 127, 142-43 (3d Cir. 1998); Rhodes v. E.I. du Pont de Nemours \& Co., 253 F.R.D. 365, 371 (S.D. W. Va. 2008); Larsen v. JBC Legal Grp., P.C., 235 F.R.D. 191, 197 (E.D.N.Y. 2006); Zehel-Miller v. Astrazeneca Pharm., LP, 223 F.R.D. 659, 664 (M.D. Fla. 2004).

178 E.g., Rowe v. E.I. du Pont de Nemours \& Co., 262 F.R.D. 451, 458 (D.N.J. 2009).

179 Barnes, 161 F.3d at 143 n.18.

1802 Alba Conte \& Herbert B. Newberg, Newberg on Class Actions § 4:34 (4th ed. 2002).

181 FED. R. CIV. P. 23(b)(3).

182 Id.

183 Sheila B. Scheuerman, Two Worlds Collide: How the Supreme Court's Recent Punitive Damages Decisions Affect Class Actions, 60 BAYLOR L. REV. 880, 883 (2008).

184 See Castano v. Am. Tobacco Co., 84 F.3d 734, $742-43$ n.15 (5th Cir. 1996).

185 Id.

186 Id.

187 Id. at 741. 
ized choice of law analysis to each plaintiff's claims, the proliferation of disparate factual and legal issues is compounded exponentially."

\section{Certifying the Medical Monitoring Class Action}

The personal injury class action no longer exists, at least in federal court. ${ }^{189}$ Recognizing this, the NFL Players have asserted only a medical monitoring claim as part of the Master Class Complaint. ${ }^{190}$ Although the Supreme Court has rejected a medical monitoring cause of action under federal law for railroad workers exposed to asbestos, ${ }^{19}$ state courts have struggled with this issue and the resulting "law of medical monitoring" has little consistency from state to state. ${ }^{192}$ For example, California has found that medical monitoring is simply a type of compensatory damages, ${ }^{193}$ while Pennsylvania has recognized medical monitoring as a "separate and distinct cause of action." the other hand, Indiana does not recognize medical monitoring at all. ${ }^{195}$ Louisiana requires a manifest physical or mental injury, ${ }^{196}$ while Missouri has found a present injury requirement to be "inconsistent with ... the purpose of medical monitoring., ${ }^{197}$

Even within those states recognizing a claim for medical monitoring, the elements vary. "Some courts have adopted a lesser standard for evaluating how much of an increase in risk plaintiffs must show to trigger the medical monitoring remedy." ${ }^{, 19}$ In addition, affirmative defenses, such as comparative negligence principles, vary among jurisdictions. ${ }^{200}$

Apparently recognizing the problems posed by multiple state laws, the NFL Players assert a medical monitoring claim under New York law only. ${ }^{201}$ The New York Court of Appeals has not addressed

188 Id. at 742-43 n.15.

189 See generally NAGAREDA, supra note 8; see also Castano v. Am. Tobacco Co., 84 F.3d 734, 746 (5th Cir. 1996) (noting that "certification of mass tort litigation classes has been disfavored").

190 See supra text accompanying notes 87-89.

191 Metro-North Commuter R. R. Co. v. Buckley, 521 U.S. 424 (1997).

192 See In re Welding Fume Prods. Liab. Litig., 245 F.R.D. 279, 291-93 (N.D. Ohio 2007) (surveying the law of medical monitoring). See generally MANUAL FOR COMPLEX LITIGATION (FOURTH) § 22.74 (2004); Anderson, supra note 10.

193 E.g., Potter v. Firestone Tire \& Rubber Co., 863 P.2d 795, 823 (1993).

194 E.g., Arch v. Am. Tobacco Co., 175 F.R.D. 469, 481 (E.D. Pa. 1997) (discussing Pennsylvania law).

195 See, e.g., Johnson v. Abbott Labs., 2004 WL 3245947, at *6 (Ind. Cir. Ct. Dec. 31, 2004).

196 See, e.g., LA. Civ. CODE ANN. art 2315 (Supp. 2004).

197 See, e.g., Meyer ex rel. Coplin v. Fluor Corp., 220 S.W.3d 712, 718 (Mo. 2007).

198 MANUAL FOR COMPLEX LITIGATION (FOURTH) § 22.74 (2004).

199 Id.

200 In re Welding Fume Prods. Liab. Litig., 245 F.R.D. 279, 292-93 (N.D. Ohio 2007) (noting that comparative negligence principles differ in Pennsylvania and Utah).

201 Master Class Action Complaint, supra note 7, II 234. 
the viability of a claim for medical monitoring, but the intermediate appellate courts and federal district courts predicting New York law consistently have allowed asymptomatic plaintiffs to bring a medical monitoring claim. ${ }^{202}$ Still, "no New York intermediate appellate court has carefully considered the elements of a claim for medical monitoring," and federal courts have described these elements in slightly different terms. ${ }^{203}$ Using the most recent articulation of these elements by a New York federal court, the NFL Players must plead:

(1) exposure at greater than background levels; (2) to a proven hazardous substance; (3) caused by defendant's tortious conduct; (4) as a proximate result of the exposure, plaintiff faces an elevated risk of contracting a serious latent disease; (5) a monitoring procedure exists that makes early detection possible; (6) the monitoring program is different that the program normally prescribed in the absence of exposure; and (7) the monitoring program is reasonably necessary according to contemporary scientific principles. ${ }^{204}$

Even assuming medical monitoring is a viable legal theory, allowing medical monitoring in the NFL-concussion litigation would expand the tort in new and novel directions. The NFL players do not allege exposure to "a proven hazardous substance," that the "repeated traumatic head impact injuries ... experienced by Plaintiffs and members of the Class" satisfy this element.

But, putting aside the substance of the plaintiffs' medical monitoring claim, a procedural question has vexed courts confronting these claims: Is medical monitoring a claim for injunctive relief or a claim for damages? ${ }^{207}$ In other words, should a medical monitoring claim be certified under Federal Rule of Civil Procedure 23(b)(2) or Rule 23(b)(3)? Courts are split on the proper approach to medicalmonitoring class actions and the viability of class treatment under either (b)(2) or (b)(3). ${ }^{208}$ The various complaints filed against the NFL reflect this split in treatment with some asserting claims under (b)(2),

202 See e.g., Caronia v. Philip Morris USA, Inc., 2011 WL 338425, at *5-7 (E.D.N.Y. Jan. 13, 2011) (discussing New York law).

203 Id. at $* 7$.

204 Id.

205 Id.

206 Master Class Action Complaint, supra note 7, II 236.

207 Compare Barnes v. Am. Tobacco Co., 161 F.3d 127, 132 (3d Cir. 1998) (describing courtsupervised medical monitoring program as "paradigmatic request for injunctive relief" but denying certification on other grounds), with Zinser v. Accufix Research Inst., Inc., 253 F.3d 1180, 1196 (9th Cir. 2001) (holding creation of medical monitoring fund was claim for monetary damages).

208 See sources cited supra note 207. 
some using (b)(3), and others cautiously covering both bases and invoking both (b)(2) and (b)(3). ${ }^{209}$

\section{A. Certification Under Rule 23(b)(3)}

National medical monitoring class actions, such as the one proposed in the Master Complaint, usually fail the predominance requirement of Rule 23(b)(3) on two grounds. First, individual issues, such as health history, frequency of exposure, causation, and the proposed treatment plan, dwarf any common issues. ${ }^{210}$ Here, causation certainly poses individual questions; each plaintiff will have to show that his brain damage resulted from concussions sustained while playing in the NFL, rather than genetic predisposition or concussions received while playing football in college or even high school. ${ }^{211}$ Moreover, numerous courts have found that the element requiring that the monitoring program be different than one normally prescribed poses individual issues. $^{212}$ Indeed, the very risk of developing CTE will vary from player to player and may depend on the position played. ${ }^{213}$ Similarly, affirmative defenses, such as comparative negligence ${ }^{214}$ or assumption of the risk, pose individual issues. ${ }^{215}$ Indeed, the NFL surely will argue that brain damage from concussions is part of the accepted risk of professional football.

Second, the variations in state law concerning the viability and elements of a medical monitoring claim prevent certification of a nationwide class action. ${ }^{216}$ Although plaintiffs attempt to circumvent this problem by requesting that only New York law apply to the class, this request runs afoul of Philips Petroleum Co.v. Shutts. ${ }^{217}$ Shutts held that every state has an interest in having its law applied to the claims of its residents. $^{218}$ Because plaintiffs are from all fifty states, all fifty state laws likely apply to the proposed class action. But, not all fifty states

209 See discussion supra part I.A.

210 See generally 1 MCLAughlin ON Class ACTIONs § 5:47 (8th ed. 2011) (discussing the application of the predominance requirement to medical monitoring claims).

211 See text accompanying supra notes 133-34.

212 E.g., Barnes, 161 F.3d at 146; Arch v. Am. Tobacco Co., 175 F.R.D. 469, 489 (E.D. Pa. 1997).

213 See discussion accompanying supra notes 135-36.

214 See, e.g., Lewallen v. Medtronic USA, Inc., 2002 WL 31300899, at *4 (N.D. Cal. 2002) (denying (b)(3) class action and identifying comparative fault defense as individual issue).

215 See, e.g., Guillory v. Am. Tobacco Co., 2001 WL 290603, at *9 (N.D. Ill. 2001) (noting assumption of the risk defense poses individual issue).

216 See, e.g., Castano v. Am. Tobacco Co., 84 F.3d 734, 742 n.15 (5th Cir. 1996); see also 1 MCLAUGHLin ON CLASS ACTIONS § 5:47 (8th ed. 2011).

217 See 472 U.S. 797 (1985).

218 Id. at $819-21$. 
even recognize a claim for medical monitoring. ${ }^{219}$ In short, a national class action under Rule 23(b)(3) is not viable for the NFL Players.

\section{B. Certification Under Rule 23(b)(2)}

Because the majority of courts have denied class certification of medical monitoring claims under Rule 23(b)(3), ${ }^{220}$ the NFL Players have turned to Rule 23(b)(2). ${ }^{221}$ Numerous courts, however, have denied class certification of medical monitoring claims under Rule 23(b)(2) for a lack of cohesiveness. In Gates v. Rohm \& Haas Co., for example, the Third Circuit noted that "medical monitoring classes may founder for lack of cohesion . . . because causation and medical necessity often require individual proof." ${ }^{224}$ Similarly, in In re St. Jude Medical, Inc., ${ }^{225}$ the Eighth Circuit concluded that "each plaintiff's need (or lack of need) for medical monitoring is highly individualized. $^{226}$ Considering a proposed medical monitoring claim for a class of heart valve recipients, the court noted that whether medical monitoring was necessary depended on "the patient's medical history, the condition of the patient's heart valves at the time of implantation, the patients risk factors for heart valve complications, the patient's general health, the patient's personal choice, and other factors." ${ }^{227}$

In short, the same individual issues that doom the (b)(3) medical monitoring class, such as causation and exposure levels, likewise create cohesiveness problems under (b)(2). ${ }^{228}$ The NFL Players will have an uphill battle demonstrating cohesion for a national medical monitoring class based on the risk of concussions. As Dr. Baugh has explained, the mechanism for CTE is unclear. ${ }^{229}$ Concussions alone are

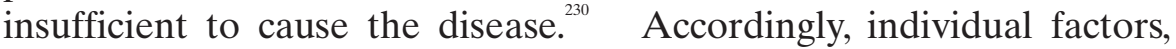
such as "duration of exposure to head trauma, age at first exposure, gender, age, race and genetic predisposition" "would need to be examined to determine whether a specific plaintiff faces an elevated risk of developing CTE. Likewise, pre-existing concussion damage from

\footnotetext{
219 See supra text accompanying notes 192-97.

220 See sources cited in 1 MCLAUGHLin ON ClAss ACTIONS $\S 5: 47$ (8th ed. 2011).

221 See supra text accompanying notes 82-83.

222 E.g., Gates v. Rohm \& Haas Co., 655 F.3d 255 (3d Cir. 2011).

223 Id.

224 Id. at 264.

225425 F.3d 1116 (8th Cir. 2005).

226 Id. at 1122.

227 Id.

228 E.g., Gates, 655 F.3d at 264-65.

229 See supra text accompanying notes 131-33.

230 See Baugh, supra note 99, at 5.

231 Id. at 9.
} 
college or high school play will need to be eliminated as a cause. ${ }^{232}$ Additionally, under Wal-Mart, the NFL must be able to present casespecific defenses, such as assumption of the risk and comparative fault. $^{233}$ Finally, given the lack of any treatment options or even markers for diagnosing CTE, ${ }^{234}$ any proposed monitoring plan cannot be in the nature of an "indivisible remedy." Given the infancy of the science in this area, it is difficult to imagine a proposed series of medical tests that would equally benefit all class members at once.

\section{CONCLUSION}

Medical monitoring claims generally do not present the type of "indivisible" claim described in Wal-Mart as appropriate under Rule 23(b)(2). If the idea under Wal-Mart is that case-specific inquiries are unnecessary because the relief benefits all class members equally, medical monitoring claims fail by definition. The elements of causation and medical necessity require consideration of case-specific facts, such as frequency and magnitude of exposure, an individual's medical history, as well as the individual risks and safety of undergoing a monitoring program. $^{235}$ Thus, liability turns on the specific facts of each class member's claimed exposure. Only where the identical risk of harm is shared among the class can a medical monitoring claim be considered "indivisible" in nature.

Moreover, under Wal-Mart, it is questionable that the Master Complaint presents a question capable of a common answer. The Master Complaint asserts that liability, affirmative defenses, medical necessity, the standards of routine medical care for men of similar age, and treatment present common questions. ${ }^{236}$ Apart from the standard of routine medical care, however, each one of these questions requires an individual answer, not a common answer. At the end of the day, should the Master Complaint survive the NFL's pending motion to dismiss, ${ }^{237}$ class certification of the medical monitoring class should be denied.

\footnotetext{
232 See Helmet Injuries Hearings, supra note 96, at 67 (statement of Dr. Robert Cantu).

3 See text accompanying supra notes 160-61.

234 See supra Part II.

235 See Gates v. Rohm \& Haas Co., 655 F.3d 255, 269 (3d Cir. 2011).

236 Master Class Action Complaint, supra note 7, II 22.

237 Memorandum of Law of Defendants National Football League and NFL Properties LLC In Support of Motion to Dismiss the Amended Master Administrative Long-Form Complaint on Preemption Grounds, In re National Football Players' Concussion Injury Litig., No. 2:12-md-02323-AB (E.D. Pa. Aug. 30, 2012), ECF No. 3589.
} 